\title{
Philosophical and Anthropological Dimension of Technoscience
}

\author{
VICTOR PETRUSHENKO, OKSANA CHURSINOVA \\ Department of Philosophy, Lviv Polytechnic National University, 5 Mytropolyt Andrei Street, Lviv, 79013, Ukraine \\ Email: vipetfil@gmail.com; churss@ukr.net
}

\begin{abstract}
The authors of this article provide arguments for the necessity to complement the existing approaches to understanding the phenomenon of technoscience with the analysis of technoscience within the context of philosophical and anthropological interpretation of technology (F. Dessauer). The article provides a critical insight into the neutral technology assessment suggested by K. Jaspers, outlines new prospects for studying technoscience taking into account the fact how a person fits into deeper structures of the world. The philosophical and anthropological interpretation of technology relates it with basic anthropic characteristics of a person, therefore, the article makes an attempt to prove that such vision of technoscience organically requires from its researchers and creators consideration of social, cultural and value-based aspects of its development and implementation.
\end{abstract}

Keywords: technoscience, basic anthropic characteristics of a person, structure of existence, technology, anthropology of technology, interdisciplinity in technoscience

\section{INTRODUCTION}

Recent discussions related to establishment and peculiarities of post-nonclassic science put lots of emphasis on the notion of technoscience. Such emphasis is understandable as there is no doubt that as we make progress our life will be marked by presence of science-intensive technologies and, on the other hand, the very development of science will more and more rely on real technological advances and directions of technological development. Almost all researchers of science stress that modern science is more and more lacking productive strategic ideas. For instance, it is stressed that since 1970s there have been no significant discoveries in the field of its fundamental aspects. Formation and modern development of technoscience means that scientific theories, scientific knowledge and scientific breakthroughs in fundamental fields of science will guarantee not only and not so much as interdisciplinary synthesis and frontal development of scientific theories, but also science-based development of complicated technologies in different fields and spheres of practical activities. Technoscience is not a combination of science and technology and is not a synthesis of science and technology, but a specific way of cognitive activity at every moment of which there are two result-oriented vectors: technical and technological, and cognitive and theoretical ones. This idea is expressed in the article by M. Yastreb, where the author illustrated changes in the relationship between 
science and technology taking place in the 20th century which marked a bigger integration of fundamental and applied researches that was reflected in the concept of the integrated field of knowledge, i.e. technoscience (Yastreb 2014: 33-37). Thus, technoscience opens promising prospects for further development of humanity and resolution of a number of topical issues of modern life that sometimes acquire a paradoxical character. For example, the idea-based breakthroughs in science can be made by the so-called scientists-generators of ideas. But such scientists should be able to see the whole problematic field of a certain science, however, the more advanced science is, the more doubtful it becomes. Technoscience offers its own way: instead of building new 'meta-storeys' over scientific theories breakthrough issues should be assigned to each separate direction of theoretical and technological search. D. Bondarenko substantiates the statement on the necessity of going from technoscience to the new stage of scientific development which is defined as megascientific (Bondarenko 2014: 169-180).

The analysis of numerous publications on technoscience (Yastreb 2014: 33-37; Argamakova 2017: 120-136; Rimkus 2017: 212-222; Bondarenko 2014: 169-180; Oikkonen 2017: 681-702; Coenen 2016: 229-231; Stoliarova 2016: 140-144; Coca, Caballero, Carrera, Paramá 2018: 185-194) shows that so far what is lacking is not that much as its unified and comprehensive understanding but also qualification of its cognitive status. Is technoscience a new stage of science development or a special branch within post-nonclassic science? Is technoscience a reality of our days or rather a projective notion that mainly indicates the prospects or tendencies of science development? Is technoscience related to all the sciences of scientific directions or has it a narrow and specialized field of application? This is a brief list of issues that should be addressed in discussions on technoscience.

In our view, in order to better understand the phenomenon of technology and evaluate its possible impact on science, knowledge and socio-cultural processes of the present time, it is necessary to choose a justifiable methodology for its analysis. The authors of this article consider using the heuristic potential of the philosophical-anthropological approach to technoscience as such methodology, because this approach essentially broadens the horizons and problems of technoscience studying and allows us to represent it in the context of humanworld relations. On the basis of such preliminary outline of the phenomenon of technoscience the authors of this research set an aim to conduct analysis of technoscience within the context of a broad or philosophical interpretation of technology. Or, if viewed at a different angle, this aim becomes a realization of technoscience phenomenon projection on that position of a person in the world which is a well-known anthropic principle of modern cosmology.

\section{TECHNOSCIENCE WITHIN THE CONTEXT OF KEY APPROACHES TO THE NOTION OF TECH- NOLOGY}

Analysis of available researches (Chernikova 2015; Chursinova 2014: 53-57) allows us to differentiate among three key approaches to the notion of technology: (1) means-based approach, according to which technology manifests itself in any man-made artificial means or equipment; (2) engineering and technological approach, according to which technology is complex artificial equipment or machines that appear as a result of human knowledge materialization and significantly enhance the efficiency of human impact on natural phenomena and processes; (3) philosophical and anthropological approach where technology is a variant (form) of manifestation of peculiarities of human interrelationship with the world (Arzakanyan, Gorokhov 1989; Epstein 2003: 410-414). This approach takes into account 
not only presence of artefacts in human life, but also the structure, mechanics, means of realization of goals and intentions of a person. For example, we can talk about fast reading technology, exercising technology, acting technology, etc. It is within the context of such interpretation of technology that it is presented as manifestation of human rationality, and F. Dessauer was convinced that human by his technical activity shows and uses those reasonable acts that were used by God to create the world (Pavlenko 2008: 325-352). K. Jaspers wrote: 'The initial enthusiasm had that sense that was preserved to our time and, according to Dessauer, shows the idea of the formation of the world that is realized via creativity of a person, who, similar to God, discovered eternal creative ideas and implemented them in the form of second nature ... Technology means both external existence and spiritual life that appeared due to internal solution' (Jaspers 1986: 136). In general, such understanding of technology can be presented in the statement: with his/her technical activity a person by means of something finite, regulated, controlled and restricted is trying to master something infinite, spontaneous, arbitrary and self-sufficient. And this way of mastering manifests itself not only in industrial processes, but also in socialization, upbringing, in adolescent mastering by a human the capabilities of his own corporeality, etc.

When it comes to the discussion of the technoscience phenomenon, then in the majority of cases technology is by default understood in the engineering and technical aspect. Such understanding becomes the basis to analyse peculiarities and possibilities of nanotechnology, biotechnology, information innovations and promising IT areas, for instance, such as artificial intelligence. However, there are no objections to the fact that the engineering and technological approach to understanding of technology disregards the issue of social, ergonomic, ethical and value-based dimensions of technology. But the more advanced machinery and technology is, the more significant its dimensions and features mentioned above become. In our opinion, one of the reasons why inventors and developers of machinery and technology abstract away from the aforementioned characteristics is the well-known Jasper's concept that neutral evaluation of technology is the most substantiated and well-grounded. Let us remind the core point: discussing the issue - which evaluation of technology - positive or negative one - is more justified, Jaspers was trying to prove that, in fact, technology in itself is neutral, while its positive or negative consequences depend exclusively on the way how it is used by a person. 'One point is obvious: technology is just means; it is not good or bad just by itself. Everything depends on how it will be used by a person, what purpose it will serve, what conditions it will be put in by a person. The key issue is what person will be in charge of technology, how this person will show himself or herself with the help of technology' (Jaspers 1986: 146). Classical and trivial demonstration of such state of things is an example with a knife that can be used to kill a person or to save a person by performing a surgery. Such interpretation of functional capabilities of technology focuses exclusively on making a person responsible for technology use, on individual training and upbringing. However, what is neglected is the fact that in any case a knife can cut the tissues or substances. Thus, in any case a knife can be used for external interference into certain things or bodies. Can one invent such a technical device that might acquire such properties under some circumstances and block them under other circumstances? - To some extent such properties can be found in pocket knives. By giving this example, we want to illustrate the idea that inventors and developers of technologies should not be guided by the belief that technology is neutral, but should try to improve it in such a way for it to be really neutral and safe for people. The very design of technical means should include possibilities for blocking the attempts of its negative or violent use. The well-known 
Russian philosopher N. Berdyaev also treated technology as neutral only during a certain period of its development and was sure that in 20th century it is necessary to give essential significance to ethics of technology, and understood its evolution in the ethical content (Berdyaev 1998: 198-199).

\section{TECHNOSCIENCE WITHIN THE STRUCTURE OF RELATIONSHIP BETWEEN THE PERSON AND THE WORLD}

Our attempt to include technoscience into the context of philosophical and anthropological interpretation of technology is stimulated by the fact that such interpretation should consider technology not as something autonomous, not as a somewhat independent way of realizing the creative potential of a person, but as such part of human existence which shows and illustrates organic inclusion of a person into the structures of both his life and the natural world. With such interpretation of technology it is impossible to step aside from anthropic dimensions of technology, from its social and cultural context and, correspondingly, from ethical and axiological aspects of its functioning. While taking into account this particular context of technology functioning developers of technology should mainly face the issue to what extent design and functioning of technology goes in line with the structure of processes and nature interactions, with the way how a person fits into these processes and interactions, to what extent all this corresponds to the social, cultural and historical experience of mankind, ethical and value-based orientations. It should be stressed that on the basis of such understanding of technology it was initiated to introduce a field of research called 'technosophy' that 'studies how technology, while meeting spiritual needs of a person, at the same time creates new spiritual aspirations ...' (Epstein 2003: 413).

All the aforementioned requirements to the development of technology become particularly important and significant when it comes to the prospects of technoscience development on the basis of biotechnologies and in the field of artificial intelligence. Certainly it is also necessary to consider nanotechnologies as they can be applied in the above-mentioned fields of technoscience development.

Another important consequence of technoscience analysis within the context of philosophical and anthropological study of science is the prospect of a deeper insight of human cognition into the subtleties of human existence in this world, organic components, elements and layers of human way of life and human origin. The current enthusiastic attempts of scientists to interfere into the genetic code of a person, into the systemic harmony of a human body, and into his/her anthropic characteristics are based exclusively on principles and ideas of engineering and technical nature leaving beyond attention the way a person fits into the whole of nature and Universe. One can be confident that further development of technology will pose more challenges to cognition, engineering and technical activities regarding these particular issues and problems. It is already a hot issue how ethical, anthropic and value-based characteristics and restrictions can be introduced in artificial intelligence programs. According to our understanding a person is quite a unique and peculiar product of nature and the Universe, its nature and peculiarities are determined by fundamental regularities and dimensions of the Universe. According to C. G. Jung (Jung 2014), human psychic is rooted into human physicality, and through it into organic and further into non-organic processes of the world, by this emphasizing its relational connections to the processes and phenomenon of nature and the Universe. Developing this idea, a contemporary investigator wrote: 'Exactly 
these roots play a crucial role in creation, establishment and functioning of conceptual elements of human orientation in the world and cognition. The primary, the most important and the most significant conceptual landmarks are reflected in culture in the form of its main symbols, as described in the works of modern scholars' (Spirova 2012: 18, 23-25).

The issue about functional restraints of artificial intelligence requires a thorough understanding and consideration of the fact as it is unlikely that programming based on modelling of natural processes can help us achieve something like this. While, on the other hand, the very idea of a person being rooted into the processes of nature and the Universe can account for the principal ambivalence of a person, i.e. its ability to perform both positive and negative destructive actions. The question arises to what extent human cognition can identify the causes of such ambivalence and consider them in the process of creation of artificial intelligence and complex automated and self-guided technical sets.

In our opinion, giving more attention to the aforementioned processes of modern technoscience development and prospects requires a closer cooperation of the whole range of sciences and scientific areas on the basis of the principles of interdisciplinary scientific research with a more active engagement into these processes of the branch of social and humanitarian sciences, such as philosophy, social and cultural anthropology, psychology, etc. However, the natural-space energy of human existence undergoes noticeable modifications, passing through its various ontological layers and structures, such as ecological conditions of the planet, social life, culture, human corporality and personality. Modern attempts to clarify the essence and prospects of technoscience clearly illustrate lack of interest to some items of its anthropological and cultural context: how the products of innovative techno-scientific experiments are going to interact and work in line with the system of social relations, legislation, ethical norms and values, human self-esteem? - All these questions become unavoidable exactly at the moment we start analysing technoscience within the context of philosophical and anthropological understanding of technoscience. Let us consider some examples. A. Argamakova takes a critical insight into the ideas that are important for technoscience theory, in particular those that link technologies exclusively to the material artifacts and machinery (Argamakova 2017: 120-136). Understanding of social technologies and innovations, social project planning and engineering, humanitarian laboratories and applied humanitarian knowledge allows us in a special way to include social and humanitarian sciences into technoscience analysis, and also to discuss their role and importance within the framework of technoscience discourse in a new light. E. Rimkus studied the relationship between everyday life and the reality revealed by contemporary science and technology (Rimkus 2017: 212-222). In her quite extensive research O. Popova provides numerous examples of those legal and moral issues that appear and sometimes acquire a conflict character due to the development of technoscientific innovations that focus exclusively on engineering concepts of machinery. In particular, it goes about monopolization on a legal basis of certain technological discoveries in the field of genetic engineering that entailed negative consequences of both legal and moral nature (Popova 2017) Thus, research programs and research teams should be formed according to this state of things.

\section{CONCLUSIONS}

In modern technology research, on the basis of the development of which techno-science was formed, dominates the engineering-technical approach to its study and understanding, which often overlooks the ethical, socio-cultural, value and personalistic aspects of its functioning. 
This shortcoming can be recompensed by an appeal to the philosophical-anthropological interpretation of technology.

While taking into account a real scale of modern technical and technological progress and its advances it is important to go beyond the engineering and technical understanding of technology and interpret it within the context of organic embodiment of a human being into the structures of the Universe, organic relations of a person with fundamental primary elements and energy of existence. Such context quite naturally leads to re-orientation of technoscience study to integral thinking, complex consideration within technoscience development of social, ethical and value-based components of human life.

It is very important that the analysis of technology in the context of the philosophical-anthropological understanding of technology involves a dual vector of research directions: on the one hand, the development of techno-science is correlated with the structures of human unity with the world, and, on the other hand, the phenomenon of techno-sciences opens the prospect of a deeper and more nuanced understanding of the sources of human and being of human.

Received 26 January 2019 Accepted 20 May 2019

\section{References}

1. Argamakova, A. 2017. 'Social and Humanitarian Dimensions of Technoscience', Epistemology \& Philosophy of Science 52(2): 120-136.

2. Arzakanyan, C.; Gorokhov, V. 1989. Philosophy of Technology in FRG. Moskva: Progress.

3. Berdyaev, N. 1998. 'About the Appointment of a Person. The Experience of Paradoxical Ethics', in On the Appointment of a Person. Moskva: Terra-Book Club/Republic, 198-199.

4. Bondarenko, D. 2014. 'Technical Science - The Necessary Step to the Mega-science", Philosophy of Science: Traditions and Innovations 2(10): 169-180.

5. Chernikova, I. 2015. Technoscience and Social Assessment of Technology (Philosophical and Methodological Analysis). Tomsk: Izdatelstvo Tomskogo universiteta.

6. Chursinova, O. 2014. 'Socio-Anthropological Aspects of Modern Ukrainian Philosophy of Technology', Visnyk Natsionalnoho universytetu 'Lvivska politekhnika'. Filosofski nauky 780: 53-57.

7. Coca, J.; Caballero, I.; Carrera, F.; Paramá, A. 2018. 'Technoscience, Hermeneutic and Society Oriented to the Person', Filosofija. Sociologija 29(3): 185-194.

8. Epstein, M. 2003. 'Technosophia', in Projective Philosophical Dictionary: New Terms and Concepts. Sankt Petersburg: Aletheia, 410-414.

9. Jaspers, K. 1986. 'Modern Technology', in New Technocratic Wave in the West. Moskva: Progress, 119146.

10. Jung, K. G. 2014. Selected Works. Sankt Petersburg: RHGA.

11. Oikkonen, V. 2017. 'Affect, Technoscience and Textual Analysis: Interrogating the Affective Dynamics of the Zika Epidemic Through Media Texts', Social Studies of Science 47(5): 681-702.

12. Pavlenko, A. 2008. 'The Possibility of Technology. Part III. Technical Project of Friedrich Dessauer', in Historical and Philosophical Yearbook. Moskva: Nauka, 325-352.

13. Popova, O. 2017. Person as a Biotechnology Artifact. Moskva: Kanon+.

14. Rimkus, E. 2017. 'Everyday Life and Technoscience', Filosofija. Sociologija 28(3): 212-222.

15. Sedykh, O.; Khamenkov, M. 2016. 'Organ Projections: Russian Context', Philosophy of Science and Technology 21(1): 132-151.

16. Semenyuk, E.; Melnik, V. 2012. Philosophy of Modern Science and Technology. Lviv: LNU imeni Ivana Franka.

17. Spirova, E. 2012. The Philosophical and Anthropological Content of the Symbol. Moskva: Kanon+.

18. Stoliarova, O. 2016. 'Technoscience as an Experimental Environment and Experimental Methodology', Epistemology \& Philosophy of Science 48(2): 40-44.

19. Yastreb, M. 2014. 'Technoscience as a Present Stage of the Development of Technical Knowledge', Perm University Bulletin. Series 'Philosophy. Psychology. Sociology' 4(20): 33-37. 
VICTOR PETRUSHENKO, OKSANA CHURSINOVA

\title{
Technomokslo filosofiniai ir antropologiniai matmenys
}

\begin{abstract}
Santrauka
Autoriai argumentuoja būtinybę papildyti vyraujančius požiūrius dèl technomokslo fenomeno sampratos analizuojant technomokslą technikos filosofinès ir antropologinès interpretacijos (F. Dessaueris) kontekste. Pateikiama kritinè neutralaus technikos vertinimo, kurị siūle K. Jaspersas, įžvalga, brèžiamos perspektyvos technomokslo studijoms, atsižvelgiant ị tai, kaip asmuo supranta gilesnes pasaulio struktūras. Filosofinès ir antropologinès technikos interpretacija siejasi su pagrindinemis antropinėmis asmens savybèmis. Straipsnyje méginama ịrodyti, kad tokia technomokslo vizija siekiant ji plètoti ir igyvendinti reikalauja, kad tyrëjai ir kūrejjai apsvarstytų socialinius, kultūrinius ir vertybinius aspektus.
\end{abstract}

Raktažodžiai: technomokslas, asmens antropinès savybès, egzistencijos struktūra, technika, technikos antropologija, technomokslo tarpdalykiškumas 